\title{
Implementasi Metode City Block Distance pada Identifikasi Citra Tanda Tangan
}

\author{
Markhamah Tri Utami ${ }^{1 *}$, Tien Rahayu Tulili ${ }^{2}$, Anton Topadang ${ }^{3}$ \\ ${ }^{1,2,3}$ Politeknik Negeri Samarinda \\ *markhamahtriu@gmail.com
}

\begin{abstract}
A signature is a certain writing style of a person's name or as a sign of identification and can be used to recognize a person's identity. Currently, the signature identification system has been applied in a number of fields, such as in forensics, psychology, and security. Stages are used in the identification of signatures has three basic stages, the stage of signature data acquisition, image feature extraction stage of the signature, and the final stages of testing the suitability of signatures. Stage signature image feature extraction is a stage that is quite important. At this stage it will look for information that is specific characteristics of each signature. So it can be used as the basis for the identity of a signature. Of these traits, City Block distance method is used to determine the suitability of the test image autograph. Based on the results of the test identification using a different image of the signature using the same person city block distance is obtained 20 images of 24 images successfully identified the success rate of $83.33 \%$.
\end{abstract}

Keywords: identification, signatures, city block distance

\begin{abstract}
Abstrak
Tanda tangan adalah gaya tulisan tertentu dari nama seseorang sebagai tanda identifikasi dan dapat digunakan untuk mengenali identitas seseorang. Saat ini, sistem identifikasi tanda tangan telah di aplikasikan pada sejumlah bidang, seperti pada bidang forensik, psikologi, dan keamanan. Tahapan yang digunakan dalam identifikasi tanda tangan memiliki tiga tahap dasar, yaitu tahap akuisi data tanda tangan, tahap ekstraksi ciri citra tanda tangan, dan terakhir tahap pengujian kecocokan tanda tangan. Tahap ekstraksi ciri citra tanda tangan merupakan tahapan yang cukup penting. Pada tahap ini akan dicari informasi-informasi yang merupakan ciri khusus dari tiap tanda tangan. Sehingga dapat dijadikan dasar untuk mendapatkan identitas dari suatu tanda tangan. Dari ciri tersebut, digunakan metode jarak City Block untuk menentukan kecocokan dalam pengujian citra tanda tangan. Berdasarkan hasil nilai uji coba identifikasi menggunakan citra yang berbeda dari tanda tangan orang yang sama dengan menggunakan jarak city block didapatkan hasil 20 citra dari 24 citra berhasil diidentifikasi dengan tingkat keberhasilan sebesar $83,33 \%$.
\end{abstract}

Kata kunci: identifikasi, jarak city block, tanda tangan

\section{Pendahuluan}

Tanda tangan adalah tulisan tangan yang dibuat dengan gaya tulisan tertentu dari nama seseorang atau sebagai tanda identifikasi lainnya yang ditulis pada dokumen dan dijadikan sebagai tanda pengenal. Fungsi dari tanda tangan adalah untuk pembuktian keaslian sebuah dokumen dan sebagai identitas seseorang pada tanda pengenal.

Tanda tangan banyak digunakan sebagai sistem identifikasi untuk mengenali seseorang.
Mengenali tanda tangan seseorang dapat dilakukan manusia secara manual yaitu dengan cara membandingkan langsung. Akan tetapi sistem pemeriksaan tanda tangan secara manual memiliki kelemahan. Alasan dari kelemahan dalam sistem pemeriksaan secara manual karena banyaknya variasi karakter tanda tangan yang menyebabkan sistem kesulitan untuk menentukan tingkat kecocokan atau keakuratan dalam membandingkan tanda tangan. Salah satu cara yang dapat digunakan 
untuk mengenali tanda tangan yaitu dengan sistem komputer. Sistem yang dapat membaca tingkat kecocokan tanda tangan seseorang sehingga mempermudah dalam mengidentifikasi tanda tangan seseorang.

Pengenalan tanda tangan dengan menggunakan sistem komputer telah menjadi suatu yang menarik perhatian sejak lama. Saat ini, sistem pengenalan tanda tangan sendiri telah digunakan pada sejumlah bidang, seperti pada bidang keamanan dan psikolog. Metode yang digunakan dalam pengenalan tanda tangan memang cukup banyak dan bervariasi, tetapi semuanya memiliki tiga tahap dasar yang sama, yaitu tahap akuisisi, tahap ekstraksi ciri tanda tangan (features extraction), dan yang terakhir tahap pengenalan tanda tangan. Tahap ekstraksi ciri citra tanda tangan merupakan tahapan yang cukup penting. Pada tahap ekstraksi ciri ini akan dicari informasi-informasi yang merupakan ciri khusus dari tiap tanda tangan masing-masing orang. Tahap ekstraksi ciri terdapat banyak, salah satunya adalah dengan menggunakan Principal Component Analysis (PCA). Dengan menggunakan PCA didapatkan nilai ciri masing-masing gambar untuk dijadikan pengujian untuk identifikasi tanda tangan.

Nilai ciri yang telah didapat selanjutnya dilakukan identifikasi. Terdapat beragam metode untuk identifikasi citra fungsi jarak. Tujuan dari penghitungan jarak adalah untuk menentukan kesamaan atau ketidaksamaan antara dua vektor fitur. Tingkat kesamaan dinyatakan dengan suatu skor atau rangking. Semakin kecil nilai rangking, semakin dekat kesamaan kedua vektor tersebut. Pengukuran jarak yang dapat dilakukan dengan menggunakan metode City Block Distance.

Dari penjelasan diatas, maka dilakukan penelitian dengan judul "Implementasi Metode City Block Distance pada Identifikasi Citra Tanda Tangan". Penelitian ini dilakukan dengan menguji nilai ciri tanda tangan masingmasing responden. Untuk mendapatkan ciri maka dilakukan tahap ekstraksi ciri dengan menggunakan PCA. Ciri yang telah dihasilkan kemudian dilakukan pengujian untuk mengetahui kemiripan dengan menggunakan metode City Block Distance. Dengan penggabungan metode tersebut diharapkan mampu menangani identifikasi tanda tangan ini dengan baik.

\section{Metoda Penelitian}

\subsection{Preprocessing}

Preprocessing merupakan suatu proses untuk menghilangkan bagian-bagian yang tidak diperlukan pada gambar input untuk memudahkan proses selanjutnya. Beberapa proses yang dilakukan pada tahapan preprocessing, diantaranya adalah cropping, konversi citra berwarna RGB menjadi citra grayscale, konversi citra grayscale ke citra biner, dan resizing image.

\subsection{Ekstraksi Ciri}

\subsubsection{Principal Component Analysis}

Principal Component Analysis adalah teknik yang digunakan untuk menyederhanakan suatu data, dengan cara mentransformasi data secara linier sehingga terbentuk sistem koordinat baru dengan varians maksimum. Pada dasarnya prosedur PCA bertujuan untuk menyederhanakan variabel yang diamati dnengan cara menyusutkan (mereduksi) dimensinya. Dengan reduksi ini maka waktu komputasi dapat dikurangi dan kompleksititas dari citra tanda tangan yang tidak perlu dapat dihilangkan tanpa menghilangkan informasi penting yang ada di dalamnya atau yang disebut dengan principal component.

Langkah umum penyelesaian PCA dengan menggunakan Matlab antara lain:

1. Input data

2. Standarisasi data

Sebelum masuk proses PCA, data pada matrik dilakukan standarisasi data terlebih dahulu dengan cara mengatur nilai mean menjadi 0 (nol) dan menyeragamkan standar deviasi.

Proses PCA
Proses PCA pada penelitian ini
menggunakan metode Eigen Value 
Decomposition (EVD). Proses PCA dengan metode EVD adalah menggunakan eigen function dari kovariprannya. Maka setelah didapat matrik covarian maka tahap selanjutnya adalah dengan mencari nilai eigen dan vektor eigen dari matrik covarian. Lalu tahap berikutnya adalah dengan mengurutkan vektor eigen berdasarkan nilai terbesar ke nilai terkecil yang disebut sebagai matrik ciri. Dari hasil EVD, matrik ciri dengan nilai eigenvalue tertinggi, merekam variasi data tertinggi. Matrik ciri yang mengandung vektor eigen dengan nilai eigen tertinggi merupakan vektor eigen yang terbaik dari matrik covarian dan dipilih sebagai nilai principal component. Nilai principal component ini yang dijadikan sebagai ciri untuk diproses selanjutnya pada tahap identifikasi.

\subsection{Identifikasi}

\subsubsection{City Block Distance}

Pada tahap identifikasi, pengujian data menggunakan pengukuran jarak City Block. City block distance juga disebut sebagai Manhattan distance. City blok distance menghitung nilai perbedaan absolut dari dua vektor. Jarak city-block didefinisikan dalam Pers. (1).

$$
j v_{1}, v_{2}=\sum_{k=1}^{N}\left|v_{1} k-v_{2} k\right|
$$

Dalam hal ini, $v_{1}$ dan $v_{2}$ adalah dua vektor yang jaraknya akan dihitung dan $\mathrm{N}$ menyatakan panjang vektor. Apabila vektor memiliki dua nilai, jarak city-block dapat dibayangkan sebagai jarak vertikal plus horizontal dari vektor pertama ke vektor kedua.

Hasil dari pengukuran kemudian dapat dibuat sebuah decision berupa identifikasi pada tanda tangan tersebut untuk mengetahui kecocokan citra yang diuji memiliki kesamaan atau tidak. Citra dinyatakan memiliki kesamaan jika nilai skor pengujian yang diperoleh berada dalam range score 0 sampai 1. Sehingga dari hasil pengukuran dapat ditentukan apakah tanda tangan yang di uji tersebut terindikasi memiliki kesamaan atau tidak dan dapat diketahui keakuratan metode yang digunakan.

\section{Hasil Penelitian}

Data yang telah melalui tahap preprocessing, kemudian dilakukan ekstraksi ciri dengan menggunakan proses PCA. Nilai ciri setiap responden ditunjukkan pada Tabel 1 .

Tabel 1. Nilai Ciri Setiap Responden

\begin{tabular}{|c|c|c|c|c|}
\hline $\begin{array}{c}\text { Tanda } \\
\text { Tangan }\end{array}$ & Bintang & Endar & Juwita & $\begin{array}{c}\text { Kak } \\
\text { Darto }\end{array}$ \\
\hline 1. & 8,4154 & 12,2246 & 16,9494 & 12,8024 \\
\hline 2. & 8,4697 & 12,3358 & 17,0846 & 12,6392 \\
\hline 3. & 8,3540 & 12,5170 & 11,8552 & 12,9486 \\
\hline 4. & 9,0852 & 11,3711 & 17,9432 & 13,5274 \\
\hline 5. & 8,4823 & 15,0707 & 12,1950 & 12,4272 \\
\hline \multicolumn{5}{|l}{} \\
\hline Tanda & Kak & Kak & Kak & Kak \\
Tangan & Lisa & Nira & Feri & Sisi \\
\hline 1 & 9,1896 & 14.2484 & 5,0714 & 9.9580 \\
\hline 2 & 9,0126 & 14.0270 & 5,0814 & 9.8405 \\
\hline 3 & 9,7069 & 13.5667 & 4,5804 & 10.7292 \\
\hline 4 & 8,9848 & 13.8417 & 6,0558 & 9.1016 \\
\hline 5 & 8,4296 & 17.8461 & 5,5937 & 9.0085 \\
\hline
\end{tabular}

Pengujian tanda tangan menggunakan citra tanda tangan yang telah dipindai menggunakan scanner sebanyak 40 data. Dari keseluruhan data yang ada, terbagi menjadi data pelatihan dan data pengenalan. Data yang digunakan sebagai data pelatihan sebanyak 16 data dan data pengenalan sebanyak 24 data. Hasil pengujian pada masing-masing mahasiswa ditunjukkan dalam bentuk tabel.

Tabel 2. Hasil Pengujian Citra Tanda Tangan Bintang

\begin{tabular}{|c|c|c|c|c|}
\hline Image & $\begin{array}{c}\text { Data } \\
\text { pelatihan }\end{array}$ & Image & $\begin{array}{c}\text { Data } \\
\text { pengenalan }\end{array}$ & Identifikasi \\
\hline 1 & 8,4154 & 3 & 8,3540 & 0.0614 \\
\hline 1 & 8,4154 & 4 & 9,0852 & 0.6698 \\
\hline 1 & 8,4154 & 5 & 8,4283 & 0.0129 \\
\hline 2 & 8,4697 & 3 & 8,3540 & 0.1157 \\
\hline 2 & 8,4697 & 4 & 9,0852 & 0.6155 \\
\hline 2 & 8,4697 & 5 & 8,4283 & 0.0414 \\
\hline
\end{tabular}

Dari Tabel 2 dapat diketahui bahwa seluruh hasil uji data pelatihan image 1, image 2 dengan uji data pengenalan yang dilakukan, nilai hasil identifikasi masing masing uji termasuk ke dalam range yang sudah 
ditentukan. Ini menunjukkan bahwa dari keseluruhan data pengenalan tanda tangan yang diujikan dianggap cocok dan dapat dikenali.

Tabel 3. Hasil Pengujian Citra Tanda Tangan Endar

\begin{tabular}{|c|c|c|c|c|}
\hline Image & $\begin{array}{c}\text { Data } \\
\text { pelatihan }\end{array}$ & Image & $\begin{array}{c}\text { Data } \\
\text { pengenalan }\end{array}$ & Identifikasi \\
\hline 1 & 12,2246 & 3 & 12,5170 & 0.2924 \\
\hline 1 & 12,2246 & 4 & 11,3711 & 0.8535 \\
\hline 1 & 12,2246 & 5 & 15,0707 & 2.8461 \\
\hline 2 & 12,3358 & 3 & 12,5170 & 0.1812 \\
\hline 2 & 12,3358 & 4 & 11,3711 & 0.9647 \\
\hline 2 & 12,3358 & 5 & 15,0707 & 2.7349 \\
\hline
\end{tabular}

Dari Tabel 3 dapat diketahui bahwa hasil uji data pelatihan image 1 dengan 3 data pengenalan yang dilakukan, nilai hasil identifikasi masing masing uji hanya 2 image termasuk ke dalam range yang sudah ditentukan yaitu pada image 3 dan image 4 . Selanjutnya untuk hasil uji data pelatihan image 2, hanya 2 image nilai hasil identifikasi masing-masing uji juga termasuk ke dalam range yang sudah ditentukan. Ini menunjukkan bahwa dari keseluruhan data pengenalan tanda tangan yang diujikan hanya 2 data yang dianggap cocok dan berhasil dikenali sebagai tanda tangan milik Endar.

Tabel 4. Hasil Pengujian Citra Tanda Tangan Juwita

\begin{tabular}{|c|c|c|c|c|}
\hline Image & $\begin{array}{c}\text { Data } \\
\text { pelatihan }\end{array}$ & Image & $\begin{array}{c}\text { Data } \\
\text { pengenalan }\end{array}$ & Pengujian \\
\hline 1 & 16.9494 & 3 & 11,9709 & 4.9785 \\
\hline 1 & 16.9494 & 4 & 17,8835 & 0.9341 \\
\hline 1 & 16.9494 & 5 & 12,4549 & 4.4945 \\
\hline 2 & 17.1584 & 3 & 11,9709 & 5.1875 \\
\hline 2 & 17.1584 & 4 & 17,8835 & 0.7251 \\
\hline 2 & 17.1584 & 5 & 12,4549 & 4.7035 \\
\hline
\end{tabular}

Dari Tabel 4 dapat diketahui bahwa hasil uji data pelatihan image 1 dan uji data pelatihan image 2 dengan ketiga data pengenalan yang dilakukan, masing-masing uji data hanya 1 image dengan nilai hasil identifikasi termasuk ke dalam range yang sudah ditentukan, Ini menunjukkan bahwa dari keseluruhan data pengenalan tanda tangan yang diujikan belum mampu mengidentifikasi tanda tangan dengan baik sehingga perlu pelajari kembali dalam pengambilan ciri.
Tabel 5. Hasil Pengujian Ciri Tanda Tangan Kak Darto

\begin{tabular}{|c|c|c|c|c|}
\hline Image & $\begin{array}{c}\text { Data } \\
\text { pelatihan }\end{array}$ & Image & $\begin{array}{c}\text { Data } \\
\text { pengenalan }\end{array}$ & Pengujian \\
\hline 1 & 12,8024 & 3 & 12.9486 & 0.1462 \\
\hline 1 & 12,8024 & 4 & 13.5274 & 0.7250 \\
\hline 1 & 12,8024 & 5 & 12.4272 & 0.3752 \\
\hline 2 & 12,6392 & 3 & 12.9486 & 0.3094 \\
\hline 2 & 12,6392 & 4 & 13.5274 & 0.8882 \\
\hline 2 & 12,6392 & 5 & 12.4272 & 0.2120 \\
\hline
\end{tabular}

Dari Tabel 5 dapat diketahui bahwa seluruh hasil uji data pelatihan image 1, image 2 dengan uji data pengenalan yang dilakukan, nilai hasil identifikasi masing masing uji termasuk ke dalam range yang sudah ditentukan. Ini menunjukkan bahwa dari keseluruhan data pengenalan tanda tangan yang diujikan dianggap cocok dan dapat dikenali sebagai tanda tangan milik Kak Darto.

Tabel 6. Hasil Pengujian Ciri Tanda Tangan Kak Lisa

\begin{tabular}{|c|c|c|c|c|}
\hline Image & $\begin{array}{c}\text { Data } \\
\text { pelatihan }\end{array}$ & Image & $\begin{array}{c}\text { Data } \\
\text { pengenalan }\end{array}$ & Pengujian \\
\hline 1 & 9.1896 & 3 & 9.7069 & 0.5173 \\
\hline 1 & 9.1896 & 4 & 8.9848 & 0.2048 \\
\hline 1 & 9.1896 & 5 & 8.4296 & 0.7600 \\
\hline 2 & 9.0126 & 3 & 9.7069 & 0.6943 \\
\hline 2 & 9.0126 & 4 & 8.9848 & 0.0278 \\
\hline 2 & 9.0126 & 5 & 8.4296 & 0.5830 \\
\hline
\end{tabular}

Dari Tabel 6 dapat diketahui bahwa seluruh hasil uji data pelatihan image 1, image 2 dengan uji data pengenalan yang dilakukan, nilai hasil identifikasi masing masing uji termasuk ke dalam range yang sudah ditentukan. Ini menunjukkan bahwa dari keseluruhan data pengenalan tanda tangan yang diujikan berhasil teridentifikasi. Tanda tangan dianggap cocok dan dapat dikenali sebagai tanda tangan milik Kak Lisa.

Dari Tabel 7 dapat diketahui bahwa hasil uji data pelatihan image 1 dengan ketiga data pengenalan yang dilakukan, nilai hasil identifikasi masing masing uji hanya 2 image termasuk ke dalam range yang sudah ditentukan yaitu pada image 3 dan image 4 . Selanjutnya untuk hasil uji data pelatihan image 2, pada image yang sama yaitu image 3 dan image 4 nilai hasil identifikasi masingmasing uji juga termasuk ke dalam range yang 
sudah ditentukan. Ini menunjukkan bahwa dari keseluruhan data pengenalan tanda tangan yang diujikan hanya 2 data yang dianggap cocok dan berhasil diidentifikasi.

Tabel 7. Hasil Pengujian Ciri Tanda Tangan Kak Nira

\begin{tabular}{|c|c|c|c|c|}
\hline Image & $\begin{array}{c}\text { Data } \\
\text { pelatihan }\end{array}$ & Image & $\begin{array}{c}\text { Data } \\
\text { pengenalan }\end{array}$ & Pengujian \\
\hline 1 & 14.2484 & 3 & 13.5667 & 0.6817 \\
\hline 1 & 14.2484 & 4 & 13.8417 & 0.4067 \\
\hline 1 & 14.2484 & 5 & 17.8461 & 3.5977 \\
\hline 2 & 14.0270 & 3 & 13.5667 & 0.4603 \\
\hline 2 & 14.0270 & 4 & 13.8417 & 0.1853 \\
\hline 2 & 14.0270 & 5 & 17.8461 & 3.8191 \\
\hline
\end{tabular}

Tabel 8. Hasil Pengujian Ciri Tanda Tangan Kak Peri

\begin{tabular}{|c|c|c|c|c|}
\hline Image & $\begin{array}{c}\text { Data } \\
\text { pelatihan }\end{array}$ & Image & $\begin{array}{c}\text { Data } \\
\text { pengenalan }\end{array}$ & Pengujian \\
\hline 1 & 5.0714 & 3 & 4.5804 & 0.4910 \\
\hline 1 & 5.0714 & 4 & 6.0558 & 0.9844 \\
\hline 1 & 5.0714 & 5 & 5.5937 & 0.5223 \\
\hline 2 & 5.0814 & 3 & 4.5804 & 0.5010 \\
\hline 2 & 5.0814 & 4 & 6.0558 & 0.9744 \\
\hline 2 & 5.0814 & 5 & 5.5937 & 0.5123 \\
\hline
\end{tabular}

Dari Tabel 8 dapat diketahui bahwa seluruh hasil uji data pelatihan image 1, image 2 dengan uji data pengenalan yang dilakukan, nilai hasil identifikasi masing masing uji termasuk ke dalam range yang sudah ditentukan. Ini menunjukkan bahwa dari keseluruhan data pengenalan tanda tangan yang diujikan dianggap cocok dan dapat dikenali sebagai tanda tangan milik orang tersebut.

Dari Tabel 9 dapat diketahui bahwa hasil uji data pelatihan image 1 dengan ketiga data pengenalan yang dilakukan, nilai hasil identifikasi masing masing uji termasuk ke dalam range yang sudah ditentukan. Selanjutnya untuk hasil uji data pelatihan image 2, hasil identifikasi masing-masing uji, nilai yang diperoleh berada dalam range yang sudah ditentukan. Ini menunjukkan bahwa dari keseluruhan data pengenalan tanda tangan yang diujikan dinyatakan cocok dan berhasil dikenali sebagai tanda tangan milik orang tersebut.
Tabel 9. Hasil Pengujian Ciri Tanda Tangan Kak Sisi

\begin{tabular}{|c|c|c|c|c|}
\hline Image & $\begin{array}{c}\text { Data } \\
\text { pelatihan }\end{array}$ & Image & $\begin{array}{c}\text { Data } \\
\text { pengenalan }\end{array}$ & Pengujian \\
\hline 1 & 9.9580 & 3 & 10.7292 & 0.7712 \\
\hline 1 & 9.9580 & 4 & 9.1016 & 0.8564 \\
\hline 1 & 9.9580 & 5 & 9.0085 & 0.9495 \\
\hline 2 & 9.8405 & 3 & 10.7292 & 0.8887 \\
\hline 2 & 9.8405 & 4 & 9.1016 & 0.7389 \\
\hline 2 & 9.8405 & 5 & 9.0085 & 0.8320 \\
\hline
\end{tabular}

\subsection{Analisa Hasil}

Dari hasil pengujian yang telah dilakukan, sebanyak lima belas image data pengenalan dari lima responden yang memperoleh nilai hasil identifikasi masingmasing uji berada dalam range 0 sampai 1 . Pada kelima respoden tersebut seluruh citra diujikan dapat teridentifikasi dengan baik. Keseluruhan citra dianggap cocok dan dikenali sebagai tanda tangan milik orang yang diujikan.

Sedangkan pada tiga responden lainnya, sebanyak enam data pengenalan yang memperoleh nilai hasil identifikasi masingmasing uji yang termasuk ke dalam range 0 sampai dengan 1. Pengujian ketiga responden ini masing-masing orang hanya terdapat dua data yang yang dianggap cocok dan berhasil diidentifikasi sebagai tanda tangan milik responden yang diujikan. Sedangkan satu responden lainnya, hanya satu image yang dianggap cocok dengan nilai hasil identifikasi uji berada dalam range yang sudah ditentukan. Maka dari keseluruhan data yang diujikan sebanyak 20 image data pengenalan memiliki kecocokan dengan ciri citra data pelatihan dan berhasil dikenali.

Berdasarkan hasil pengujian yang telah dilakukan dapat diketahui tingkat keakuratan metode yang digunakan pada identifikasi citra tanda tangan dalam bentuk persentase. Tingkat akurasi citra tanda tangan dinyatakan cocok dengan ketentuan jika citra tanda tangan yang diuji diperoleh hasil kurang dari sama dengan satu $(<=1)$. Nilai presentase dari tingkat akurasi keberhasilan dalam mengenali tanda tangan dapat dihitung dari, total jumlah tanda tangan yang cocok dibagi dengan jumlah tanda tangan uji dikalikan $100 \%$. 


$$
\frac{20}{24} \times 100 \%=83,33 \%
$$

Dari hasil pengukuran tingkat akurasi diatas, tingkat keberhasilan metode City Block Distance dalam identifikasi ciri citra dengan tanda tangan berbeda pada responden yang sama sebesar $83,33 \%$.

\section{Kesimpulan}

Data yang digunakan berupa tanda tangan dengan jumlah 40 tanda tangan dari 8 mahasiswa. Dari keseluruhan data yang ada, data yang digunakan sebagai data latih sebanyak 16 data dan data pengenalan sebanyak 24 data.

Pencarian ciri yang dilakukan pada masing-masing tanda tangan menggunakan perhitungan Principal Component Analysys. Proses identifikasi untuk mencari kecocokan dengan menggunakan metode City Block.

Dari keseluruhan data yang diujikan, sebanyak 20 image data pengenalan berhasil teridentifikasi memiliki kecocokan dengan data pelatihan.

Hasil pengujian identifikasi citra tanda tangan menggunakan City Block Distance diperoleh tingkat keberhasilan sebesar $83.33 \%$. Menunjukkan bahwa metode City Block Distance cocok digunakan untuk identifikasi citra tanda tangan.

\section{Saran}

Citra hasil preprosesing dan ekstraksi ciri masih kurang baik, sehingga pada saat dilakukan pengujian beberapa data diperoleh hasil yang kurang akurat. Untuk mendapatkan hasil akurasi yang lebih baik maka disarankan:

1. Akuisi data harus lebih baik sehingga ciri yang didapatkan dapat lebih baik. Hasil dari proses ekstraksi ciri yang diperoleh dapat lebih baik.

2. Sebaiknya jumlah data yang digunakan lebih banyak.

\section{Daftar Pustaka}

[1] M. R. Faisal, 2017. Seri Belajar Pemrograman Supervised Learning dengan R (Volume 1 dari Seri Belajar Pemrograman), www.rezafaisal.net, diakses tanggal 20 Januari 2017.

[2] R. D. Intan dan E. M. Imah, "Studi Komparasi Ekstraksi Fitur pada Pengenalan Wajah Menggunakan Principal Component Analysis (PCA) dan Wavelet Daubechies," Jurnal Masyarakat Informatika, vol. 6, no. 11.

[3] R. R. Isnanto, A. A. Zahra, E. D. Widianto, "Analisis Kinerja Pengenalan Telapak Tangan Menggunakan Ekstraksi Ciri Principal Component Analysis (PCA) dan Overlapping Block," Scientific Journal of Informatics, vol. 2, no. 2, 2015.

[4] A. Kadir dan A. Susanto, 2012. Pengolahan Citra. Yogyakarta: Andi Offset.

[5] D. Putra, 2010. Pengolahan Citra Digital. Yogyakarta: Andi Offset.

[6] G. Romadhon dan Murinto, "Aplikasi Pengenalan Citra Rambu Lalu Lintas Berbentuk Lingkaran Menggunakan Metode Jarak City-Block," Jurnal Sarjana Teknik Informatika, vol. 2, no. 2, 2014.

[7] D. Satria dan Mushthofa, "Perbandingan Metode Ekstraksi Ciri Histogram dan PCA untuk Mendeteksi Stoma pada Citra Penampang Daun Freycinetia," vol. 2, no. 1, 2013.

[8] I. M. G. Sunarya, "Sistem Biometrika Identifikasi Tanda Tangan Menggunakan Metode Jaringan Syaraf Tiruan Model Perceptron," Jurnal Informatika, vol 7, no. 1, 2013.

[9] Suriyati, "Identifikasi Telapak Tangan (Palmprint) Dengan Ekstraksi Fitur Dimensi Fraktal Dan Lacunarity," Prosiding Konferensi Nasional Inovasi dalam Desain dan Teknologi, 2011.

[10] www.kbbi.co.id, diakses tanggal 20 Januari 2017. 